\title{
Cost Comparison and Hydraulic Design of Four Types of Residential Rainwater Harvesting Systems for Small Rural Communities, Considering Natural or Anthropogenic Climate Change Factors
}

\author{
Martín Mundo-Molina, Eber Godinez, José Luis Pérez-Díaz, Daniel Hernández \\ Engineering Faculty, Chiapas State University, Tuxtla Gutiérrez, México \\ Email: ic_ingenieros@yahoo.com.mx
}

How to cite this paper: Mundo-Molina, M., Godinez, E., Pérez-Díaz, J.L. and Hernández, D. (2018) Cost Comparison and Hydraulic Design of Four Types of Residential Rainwater Harvesting Systems for Small Rural Communities, Considering Natural or Anthropogenic Climate Change Factors. Journal of Water Resource and Protection, 10, 1115-1128.

https://doi.org/10.4236/jwarp.2018.1011066

Received: October 19, 2018

Accepted: November 12, 2018

Published: November 15, 2018

Copyright (c) 2018 by authors and Scientific Research Publishing Inc. This work is licensed under the Creative Commons Attribution International License (CC BY 4.0).

http://creativecommons.org/licenses/by/4.0/

\section{(c) () Open Access}

\begin{abstract}
This document presents the technical description and cost comparison of four rainwater harvesting systems for homes, the method for its hydraulic design and an equation to estimate the minimum catchment area, with the goal to supply drinking water to segregated small communities in Mexico considering climate change effects, both natural and anthropogenic. The four Rainwater Harvesting Systems (RHS) introduced in this work are the following: two rigid, one system built with ferrocement and the other built with clay bricks, and two flexible: one is a commercial collector while the other is a system built with a 3/8-inch reinforcing bar mesh and covered with a linear low-density polyethylene geomembrane. The RHS consist in cylindrical containers built with diverse materials, and in the case of rigid RHSs, they can store up to 50,000 liters of water. Also, rigid RHSs have a longer useful life and are more resistant than flexible RHSs, but their cost is notably higher. Rigid RHSs compete in price with commercial rainwater harvesting system brands like Rotoplas, but commercial RHSs disadvantages are their lower durability, storage capacity, and resistance. On the other hand, flexible RHSs are less durable than rigid ones, although, in the case of the rainwater harvesting system made with a 3/8-inch reinforcing bar mesh, the system can be rebuilt and reused and the cost is much lower. The design of the collectors takes into consideration the climate variability of the study area, natural or anthropogenic.
\end{abstract}

\section{Keywords}

Rainwater Harvesting Systems, Rural Communities, Hydraulic Design 


\section{Introduction}

In the world, 1100 million people do not have access to potable water, and 2400 million people lack basic sanitation. In the American continent, more than 100 million people in urban settings still live without services, and around 120 million people need a secure water supply [1]. In dozens of countries from Asia, Africa and Latin America (LA), there exists a severe deficit in water for human consumption and food production. Even though South America has two of the most essential drainage basins, the Amazon basin with a discharge of 212,000 $\mathrm{m}^{3} / \mathrm{s}$, and the Rio de la Plata basin with a discharge of $42,400 \mathrm{~m}^{3} / \mathrm{s}$ [2] there are hundreds of communities in Brazil, Colombia, Bolivia, Peru, Venezuela, Paraguay, Uruguay and Argentina with problems related to water deficit for human consumption and for food production. Regarding drinkable water and sanitation, 78 million of people in LA hasn't access to water sources, and, 117 millions of people lacks sanitation services, most of all in rural areas or poor suburbs in big cities [3].

Concerning food production in Latin America, irrigated agriculture is the activity that consumes the largest volume of water, up to $60 \%$, yet some countries surpass that percentage, like Mexico. Mexico's most important agriculture areas are in the north of the country, in the arid and semi-arid regions, where there is a severe water deficit problem. Irrigation in the north area of the country consumes $80 \%$ of the total water used, with an efficiency of $50 \%$ [4].

Water supply problems in Latin America and the rest of the world are the result of many factors like population growth, polluted water bodies, communities living in arid areas or with water deficit, deforestation, and land-use change, inefficient water use, inadequate public policies, national poverty, lack of infrastructure and political corruption. Exponential population growth affects the other factors directly and when we add the natural distribution of water on Earth, the crisis of water supply for agriculture, production of energy, goods and services increases, especially in impoverished countries. In the book Synthesis of the IV World Water Forum, the following quote can be read in page 4: “...many of the poorest countries in the world, those with acute need of better water services and that face more significant challenges than richer countries for their climate vulnerability, have an insufficient hydraulic infrastructure and experience in water management. Consequently, the challenges they face today are higher than those overcome by developed countries" [1].

Even though Latin America has the largest availability of fresh water per capita, its inadequate distribution, pollution, and scarcity have intensified, provoking that governments in the last decades have implemented plans for its exploitation and commercialization. Even big transnational corporations and countries from other latitudes show interest in contributing to the privatization process of services that provide and distribute fresh water to the population and local industries. Farmers, indigenous communities, and large population sectors have gathered in various Latin American nations to defend their access to fresh water 
and oppose its privatization [2]. Cochabamba's case in Bolivia is emblematic and an example for Latin America. [5] mentions that for several years, neoliberal governments have promoted decentralization politics for the management of superficial and subterranean water, to allow multinational companies to establish agreements with municipalities for control over water resources. This kind of arrangements is backed up by financial entities like the World Bank or the Inter-American Development Bank, and in many instances, there has been no control or participation from the legislative power of each country or the national states when these accords take place.

For example, in 2015 in Mexico, the government emitted a decree from the new "National Waters Law" named "Korenfeld Law", without consultation and active participation from universities, researchers and professional associations of the country. The decree was discarded thanks to the pressure exercised by the citizens through public opinion. Korenfeld Law was recently relaunched as the "Pichardo Law" in June 2018, and just like in 2015, it has generated extensive debates and rejection from the people in the country for various reasons, but mainly because the law announces, in a subtle way, the privatization of water management, which would attempt against the human right to water access, primarily of rural communities in Mexico, the law also liberates the interbasin water transfer and it does not establish clear rates for water consumption, especially for irrigation which is the sector that consumes the most water and equally enjoys state subsidy in electrical energy usage, and a rate policy that promotes water misuse. Concerning this matter, the LAN, in fraction XVIII of the third article of the National Waters Law published in 1992 states that the recovery costs or self-sufficiency fees are: “...those destined to recuperating the costs derived from the operation, conservation and maintenance of hydraulic infrastructure works, facilities and irrigation areas, as well as the costs for investment in infrastructure, mechanisms, and equipment, that includes its improvement, rehabilitation, and replacement. The self-sufficiency fees don't pay taxes and are paid by irrigation users in the districts, units and agricultural boards or other associations that use water for agricultural irrigation..." [6]. In practice, this law is not only ambiguous but also is inoperant and it requires review because the state does not demand payment for the dams' maintenance and operation, the hydraulic infrastructure nor the workforce before they deliver water to the irrigation associations from the transferred districts. The fees promote the inefficiency of water management, for example, in the irrigation district (ID) 044 in Jilotepec, Estado de Mexico, the cost of water for irrigation is priced according to the volume of water extracted monthly. The cost for using water in this ID fluctuates between the 0.0000579 USD and 0.00317 USD (depending on the crop) for each 1000 liter of water used [7]. Those are absurd fees that go against the proper use and efficiency of this resource.

The unfolding panorama makes us expect, in a not so distant future, the increase of conflicts over water in Latin America. [8] estimates that in 2025, water 
demand in the world will be $56 \%$ greater than water supply, and many countries that today have enough water per capita could go in a deficit. For example, in Table 1, Peru is considered in the "sufficient" range because its water availability per capita is of $1709 \mathrm{~m}^{3} /$ year, however, according [2], it is quite possible that before 2025 its availability decreases to $980 \mathrm{~m}^{3} /$ year per capita, which would mean that Peru would move into the "water deficit" category.

According to [9] the amount of water per capita in Mexico for 2015 was of $3692 \mathrm{~m}^{3} /$ year, which means Mexico is in the "sufficient" range but, there is a high possibility that for 2020 water availability decreases to $3500 \mathrm{~m}^{3} /$ inhabitant/year [10]. However, if the current contamination process of the rivers, streams, and freshwater bodies continues, plus the exponential population growth, in few decades, it could move into the "regular" level, or even into "water deficit" category.

It's evident that the water availability problem will cause conflicts and fights between groups with different interests and in diverse levels: local, regional, national and global. These conflicts have already started in Mexico. According to [12] during the 1990-2002-year period, from the total amount of conflicts in Mexico 49\% happened in Mexico City and Estado de Mexico, 14\% in the north area of the country, $13 \%$ in the south, $9 \%$ in the north-central territories, $9 \%$ in the east and the rest in the northwest and west areas. It's not surprising that most of the conflicts happen in a city with excessive water consumption as Mexico City, with its more than 20 million inhabitants [13]. Mexico City uses water through interbasin transfer, which means it uses water that comes from other provinces, like Estado de Mexico and Michoacán. On the other hand, [12] affirms that $60 \%$ of conflicts originate in places where overexploited aquifers are located. These authors classified in percentages the demands of the population when water conflicts arise, so $56 \%$ of the conflicts are demands for water supply, $24 \%$ requests to lower the prices, $6 \%$ demand hydraulic infrastructure, $2 \%$ demand to rescue overexploited aquifers and the remaining $12 \%$ is not classified yet.

\section{Water Problems in Mexico and Rainwater as a Usable Resource}

According to [14] in 2015 the coverage of water distributed through pipelines in Mexican homes was of $97.2 \%$ in urban areas and $85 \%$ in rural areas. That means that at least 3.5 millions of Mexicans in urban areas lack fresh water and a little

Table 1 . Water availability categories [11].

\begin{tabular}{cc}
\hline Very Rich & More than $1000,000 \mathrm{~m}^{3} /$ habitant/year \\
\hline Rich & From 10,000 to $1000,000 \mathrm{~m}^{3} /$ habitant/year \\
Sufficient & From 2000 to $10,000 \mathrm{~m}^{3} /$ habitant/year \\
Regular & From 1000 to $2000 \mathrm{~m}^{3} /$ habitant/year \\
Water deficit & Less than $1000 \mathrm{~m}^{3} /$ habitant/year \\
\hline
\end{tabular}


bit over 18.5 million people that live in rural areas do not have access to water at all. As an example, in the state of Chiapas, more than 18,160 small indigenous communities with less than 500 residents each don't have access to water. This problem is more significant in hundreds of indigenous communities living in the highlands [15]. The indigenous communities (IC) are the most affected by water deficit, and Mexico has an indigenous population slightly higher than ten million people, distributed through the entire national territory [16]. Indigenous communities have lived in unhealthy conditions for hundreds of years, with a scarcity of necessary infrastructure to subsist with dignity [17] [18]. The $27 \%$ of the 2443 municipalities in Mexico have $40 \%$ of indigenous people, the vast majority living in precarious conditions because of deficiency of water and decent housing. Water provision through conventional methods for hundreds of IC remains an unsolved problem [19]. Freshwater for domestic use and human consumption (which are fundamental human rights) are still a utopia for thousands of IC in Mexico and Latin America.

A way to decrease the water supply problems in Mexico is to reuse treated wastewater. According to [20] there are 1500 wastewater treatment plants, yet most of them don't reuse treated water. For example, in El Naranjo wastewater treatment plant in Ensenada Baja California, $99 \mathrm{Mm}^{3}$ of treated wastewater, valued in 13.9 $\mathrm{M}$ of USD, was lost in the last 9 years by spilling it into the Pacific Ocean. Mexico discharge daily a total of $426 \mathrm{~m}^{3} / \mathrm{s}$ of wastewater and only $94 \mathrm{~m}^{3} / \mathrm{s}$ is treated, which means $80 \%$ of the flow is not used. Ironically, from the $332 \mathrm{~m}^{3} / \mathrm{s}$ of untreated wastewater, almost $160 \mathrm{~m}^{3} / \mathrm{s}$ is used for crop irrigation in the Mezquital valley in Hidalgo and Valle de Juárez in Chihuahua. For this reasons, Mexico should promote by law the obligatory reuse of treated wastewater [20].

Mexico not only misuses wastewater, but also rainwater, which is a much more relevant resource by its annual volumen than wastewater. The national water law must include rainwater harvesting not only to force the different sectors of the country to use this resource but also to regulate its management and set the technical terms for its adequate harvest according to its possible use. Rainwater use must be established as an obligatory act in the public works and construction regulations of Mexico, so that institutions working in the engineering branch include, by law, the use of this resource.

To understand the waste of rainwater in the country, we state the following data: Mexico has an area of more than 2 million $\mathrm{km}^{2}$, divided into 32 states or provinces. Most of the surface of the country has arid and semi-arid regions that form $53.4 \%$ of the territory. Twenty five of the 32 states in the Mexican Republic have arid portions, especially those in the desert strip ( $30^{\circ}$ latitude), and seventeen of the 32 states are below the country's average annual precipitation, which is $875 \mathrm{~mm} /$ year, according to climate normals from the 1971-2000 period [21]. Baja California Sur located in the northeast of the country has the lowest annual precipitation with $161 \mathrm{~mm} /$ year, and Tabasco located in the tropical strip of the south has the highest with $2102 \mathrm{~mm} /$ year. Table 2 depicts the average annual 
Table 2. Average annual precipitation in Mexico [21].

\begin{tabular}{|c|c|c|c|c|c|c|c|}
\hline NUMBER & STATE & $\begin{array}{l}\text { PRECIPITATION } \\
\text { (mm/year) }\end{array}$ & $\begin{array}{c}\text { AREA } \\
\left(\mathrm{km}^{\wedge} 2\right)\end{array}$ & POPULATION & $\begin{array}{l}\text { RUNOFF ON RIVERS } \\
\left(\left(\mathrm{Mm}^{\wedge} 3\right)\right.\end{array}$ & $\begin{array}{c}\text { GROUND } \\
\text { WATER }\left(\mathrm{Mm}^{\wedge} 3\right)\end{array}$ & $\begin{array}{c}\text { TOTAL POTENTIAL } \\
\text { RUNOOF }\left(\mathrm{Mm}^{\wedge} 3\right)\end{array}$ \\
\hline & & $(1971-200)$ & & (MILLIONS) & & & \\
\hline 1 & Baja California Sur & 161 & 75,675 & 544,556 & 32 & 367 & $12,183.675$ \\
\hline 2 & Baja California & 175.7 & 71,450 & $3,036,393$ & 1665 & 1439 & $12,553.765$ \\
\hline 3 & Coahuila & 379 & 151,571 & $2,587,917$ & 890 & 1050 & $57,445.409$ \\
\hline 4 & Sonora & 421.2 & 179,355 & $2,475,568$ & 4577 & 2817 & $75,544.326$ \\
\hline 5 & Zacatecas & 460.8 & 77,684 & $1,381,991$ & 329 & 1099 & $35,796.7872$ \\
\hline 6 & Chihuahua & 462 & 247,455 & $3,343,408$ & 1958 & 3191 & $114,324.21$ \\
\hline 7 & Aguascalientes & 512.5 & 5616 & $1,115,304$ & 177 & 0 & 2878.2 \\
\hline 8 & Durango & 570.6 & 125,381 & $1,541,433$ & 739 & 820 & $71,542.3986$ \\
\hline 9 & Nuevo León & 584.5 & 64,924 & $4,365,090$ & 1144 & 874 & $37,948.078$ \\
\hline 10 & Guanajuato & 596.8 & 30,608 & $5,008,063$ & 1340 & 2719 & $182,66.8544$ \\
\hline 11 & San Luis Potosí & 692.5 & 65,268 & $2,467,651$ & 587 & 747 & $45,198.09$ \\
\hline 12 & Tlaxcala & 700 & 4016 & $1,112,200$ & 72 & 211 & 2811.2 \\
\hline 13 & Querétaro & 724.4 & 11,699 & $1,674,737$ & 322 & 697 & 8474.7556 \\
\hline 14 & Sinaloa & 730.1 & 58,200 & $2,645,933$ & 8243 & 921 & $42,491.82$ \\
\hline 15 & Tamaulipas & 763.6 & 75,384 & $3,135,501$ & 3415 & 360 & $57,563.2224$ \\
\hline 16 & Hidalgo & 831.8 & 20,813 & $2,402,682$ & 1947 & 389 & $17,312.2534$ \\
\hline 17 & Estado de México & 850.6 & $22,499.95$ & $14,536,860$ & 1240 & 1512 & $19,138.45747$ \\
\hline 18 & Jalisco & 893.1 & 78,588 & $6,931,957$ & 2111 & 1553 & $70,186.9428$ \\
\hline 19 & Michoacán & 911.1 & $58,598.7$ & $3,984,577$ & 3933 & 1136 & $53,389.27557$ \\
\hline 20 & CDMX & 937.4 & 1495 & $8,832,734$ & 310 & 813 & 1401.413 \\
\hline 21 & Colima & 964.4 & 5625 & 589,327 & 1344 & 307 & 5424.75 \\
\hline 22 & Morelos & 981.4 & 4950 & $1,655,138$ & 878 & 355 & 4857.93 \\
\hline 23 & Puebla & 1034.1 & 34,251 & $5,567,191$ & 1380 & 1103 & $35,418.9591$ \\
\hline 24 & Yucatán & 1066.6 & 43,379 & $1,886,161$ & 0 & 1103 & $46,268.0414$ \\
\hline 25 & Oaxaca & 1181.8 & 93,952 & $3,552,685$ & 732 & 355 & $111,032.4736$ \\
\hline 26 & Nayarit & 1185.8 & 27,857 & 965,641 & 992 & 194 & $33,032.8306$ \\
\hline 27 & Guerrero & 1195 & 64,281 & $3,147,680$ & 4033 & 226 & $76,815.795$ \\
\hline 28 & Quintanarro & 1234.4 & 50,212 & $1,243,989$ & 1 & 459 & $61,981.6928$ \\
\hline 29 & Campeche & 1336.8 & 57,924 & 782,130 & 61 & 558 & $77,432.8032$ \\
\hline 30 & Veracruz & 1610.6 & 71,826 & $7,251,626$ & 4028 & 563 & $115,682.9556$ \\
\hline 31 & Chiapas & 1763.9 & 73,211 & $4,435,911$ & 1260 & 417 & $129,136.8829$ \\
\hline 32 & Tabasco & 2102 & 25,267 & $2,034,507$ & 264 & 132 & $53,111.234$ \\
\hline
\end{tabular}


precipitations, river runoff, and runoff potential derived from the rain in each state of the Mexican Republic.

In the state of Colima, which has a surface of $11,600 \mathrm{~km}^{2}$ rain generates a runoff potential of more than $1864 \mathrm{Mm}^{3}$ annually, a similar number to unused treated wastewater in the country. Mexico's runoff potential is over 1.5 billion of $\mathrm{m}^{3}$, however according to [9] states that from the total water Mexico receives from precipitation, $73 \%$ evaporates, $6 \%$ infiltrates the soil and $22 \%$ becomes runoff. Considering these percentages the amount of rainwater wasted in the country ascends to $331,463 \mathrm{Mm}^{3}$ approximately, which means that wasted rainwater volume 6.5 times higher than the volume of water licensed to thousands of users in 2015 (the volume of water licensed to thousands of users was 52,353 $\mathrm{Mm}^{3}$ to 121,514 institutions). By all reasons explained in before paragraphs, the rainwater must be collected in large cities and rural areas through rainwater harvesting systems, as stated by [15].

\section{The RHS}

Many types of RHS exist, such as brick tanks or ferrocement tanks [22] or the ones mentioned by [23] who in his technical document describes concrete, concrete block, metallic and wood tanks. There are even very large community water tanks, such as the one described in [15]. All these types of RHS are different in size, cost, and geometry. The four RHS introduced in this work are cylindrical and equivalent in many of their characteristics, they also begin to be used in Mexico.

\subsection{General Description}

The RHS is a cylindrical deposit, as pictured in Photo 1, that receives rainwater from the rooftops through a gutter, to supply good quality water to every family member in a household. The deposit can be built with a capacity for 5000, 10,000, $20,000,30,000$ or even 50,000 liters of water. For example, the "cappuccino RHS" has been built before with a 50,000 liter capacity (Photo 2). The RHS has a lid that isolates its contents from the exterior to avoid external pollutants (dust, gases, and air particles), at the bottom, the RHS has a pipe and a tap with a valve for water supply.

\subsection{Equations for Hydraulic Design, Considering Climate Change Effects}

For the RHS's hydraulic design, we used equation [1], mentioned in [15]:

$$
V=(D)(H)\left(t_{a}\right)
$$

where $V$ is the RHS's volume in $\mathrm{m}^{3}, D$ is the daily water supply per capita in $\mathrm{m}^{3} /$ habitant/d, $H$ is the number of people that inhabit the house and $t_{a}$ is the maximum water storage time in days. Using the conservation of mass principle in its volumetric version, equation 1 can be written the following way [15]: 


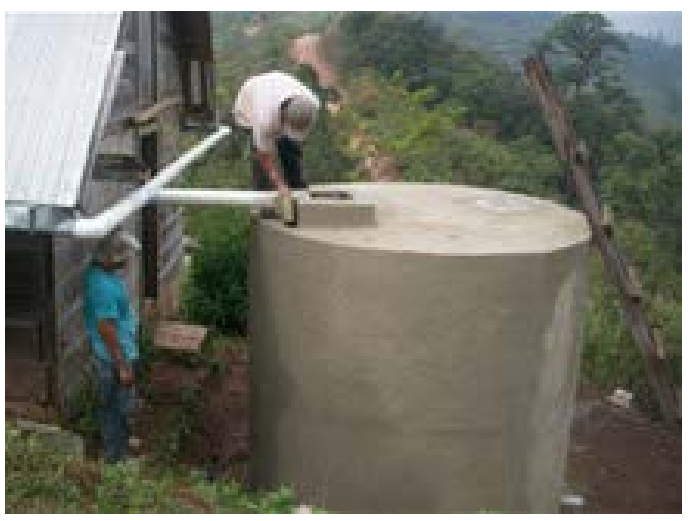

Photo 1. Cylindrical CALLD [24].

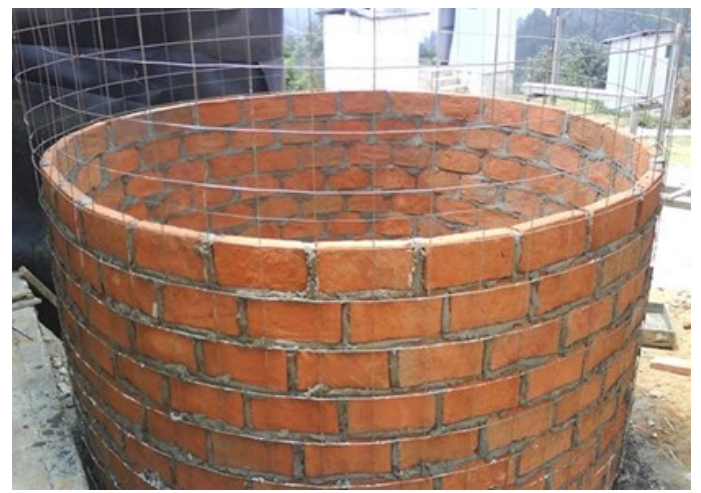

Photo 2. Rigid brick CALLD.

$$
Q t=(D)(H)\left(t_{a}\right)
$$

If $Q$ in the home's roof is calculated with Equation (3):

$$
Q \sim P A_{c}
$$

where:

$P=$ Normal average annual precipitation (m/a).

$A_{c}=$ Catchment area in a household rooftop $\left(\mathrm{m}^{2}\right)$.

So, substituting Equation (2) in Equation (3), and isolating $A_{c}$ :

$$
A_{c} \sim \frac{(D)(H)\left(t_{a}\right)}{(P)}
$$

Thus, in order to equalize the equation before was introduced it the factor 1/Fs [15]. The Equation (4) allows us to estimate the minimal catchment area in a household, to find the volume of water the family demands:

$$
A_{c}=\frac{(D)(H)\left(t_{a}\right)}{(P)(F c)}
$$

Fc's value is different in each study site and it depends on precipitation and climate variability, natural or anthropogenic climate change, of the study area. The term "climate change" is used excessively and irresponsibly. We can't talk about climate change effects or climate variability of an area without examina- 
tion that such change or variability exists (as many studies tend to do). We must corroborate with data from several weather stations on site (one is not enough), and we should employ different study methods for each particular case. Climate variability or climate change is represented as "climate factor Fc" in Equation (4). According to the World Meteorological Organization (WMO), highland areas must have daily records of precipitation from the last 50 years, and valleys must have 30 years of records. Missing data must be filled in following the guidelines set by [25].

The filling of missing data and verification of the homogeneity of time series of weather stations is essential. So the WS method and the "Standard Normal Homogeneity Test" (SNHT), the Von Neumann method or the Buishand method, must be used, respectively. Afterward, we must analyze P anomalies, and its increase or decrease tendencies in the time series, before affirming that climate change exists in the study area [26]. Finally, we calculate the Fc, in other words, the anomalies of the daily precipitation series of the last 50 or 30 years according to the available data of the study zone.

Before using equation 4, we must consider the following aspects: according to polls done on study site, the average volume of water supplied (D) in indigenous communities is $30 \mathrm{l} / \mathrm{inh}$ abitant/d (exclusively for drinking and domestic use), however the World Health Organization (WHO) suggests a daily water supply of 50 liters per inhabitant a day, to make sure that a person can cover their basic needs and no health threat arises.

Concerning the value of $\mathrm{H}$ in the equation, it is essential to understand that indigenous families are large, between 5 and 10 members per family. Storage time $\left(t_{a}\right)$ varies depending on the region, so we suggest using the period low water levels as the maximum value. For the $\mathrm{P}$ value, we recommend using the normal average annual precipitation in $\mathrm{m} / \mathrm{a}$.

\subsection{RHS Rigid: Kind Cappuccino}

The wall "kind cappuccino" is shown in the Photo 2, by this reason the RHS of Photo 2 is called "RHS cappuccino", it is built with a brick masonry wall and has a circular base of reinforced concrete with wire mesh (6-6/10-10) $5 \mathrm{~cm}$ thick, tied to the cylindrical structure, constructed with the same wire mesh. The external wire mesh supports the brick wall. The finish on both sides of the cylinder (internal and external surfaces) is grout (Photo 3). The "RSH cappuccino" has a concrete lid with an opening on top where water comes from the house's roof enters the tank throught of water pipe. The water pipe has an inverted siphon that traps trash and suspended solids to keep the water clean. There are "RSH cappuccino" with 50,000-liter capacity constructed in the Mexican Institute of water Technology in Mexico.

\subsection{RHS Rigid: Ferrocement}

The Ferrocement RHS is a construction made of reinforced concrete, with walls 5,7 and $10 \mathrm{~cm}$ thick (the width of the walls depends on the amount of water to 


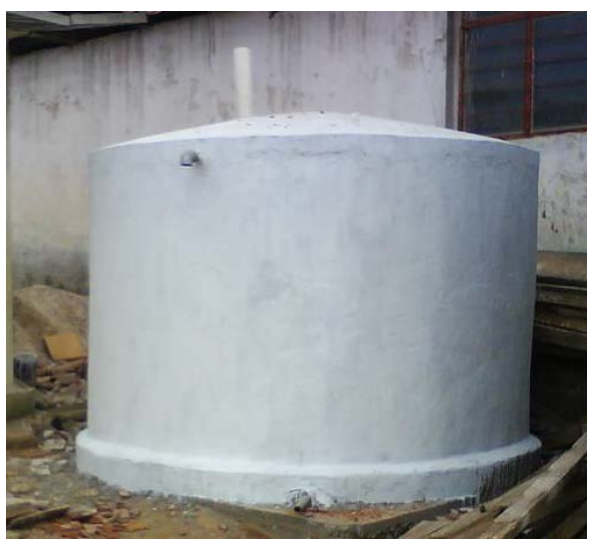

Photo 3. Rigid CALLD with final finish.

be stored in the container). The construction method of a ferrocement RSH is simple: after cleaning the plot and preparing the layout, we build the foundation with a concrete pad and a 6-6/10-10 electro-welded mesh tied to the bar mesh cylindrical structure, as in Photo 4 . The foundation must be $5 \mathrm{~cm}$ thick and with a concrete resistance of $\mathrm{f}^{\prime} \mathrm{c}=100 \mathrm{~kg} / \mathrm{cm}^{2}$. Once the frame is done, we place a timber formwork with a $5 \mathrm{~cm}$ separation to pour the concrete, and as soon as the concrete is setting time, we apply a mortar finish, as seen in Photo 5.

The ferrocement RHS for homes is a technology used by the State Water Institute (INESA in its Spanish acronym) of Chiapas, Mexico, who have built ferrocement RHS with a capacity up to 15,000 liters in several rural communities in Chiapas, like the one in Photo 5 [24].

\subsection{RHS Flexible}

\subsubsection{RHS Commercial Flexible}

The RHS commercial flexible is rotoplas storage tanks (RST). The RST flexible is a cylindrical container made of quality high density polyethylene (HDPE) for strength and durability, making RST tanks resistant to extreme weather conditions. RST uses UV-inhibiting resins to prevent content degradation, preserving the integrity of substances stored within. The RST of 4500 gallons (15, 518 litros approximately) named Aqua $4100 \mathrm{~V}$ Green has 102 diameter inches and 130 height inches.

\subsubsection{RHS Flexible}

The RHS flexible is a cylindrical container with a wire structure wrapped in low-density polyethylene, shown in Photo 6. For a 5000-liter capacity RHS flexible, is reinforced the structure with an electro-welded mesh and vertical metal stems (Photo 6). Containers with a larger volume, like 10,000 or 15,000 -liter tanks, must have a reinforced structure made of 3/8-inch electro-welded mesh covered with a low-density polyethylene geomembrane, with metal stems positioned around the tank in an octagon shape and a circular support piece welded with the stems to stiffen the structure and secure the geomembrane. The lid of the RHS flexible is a circular piece, made with a gauge 12 galvanized steel sheet. 


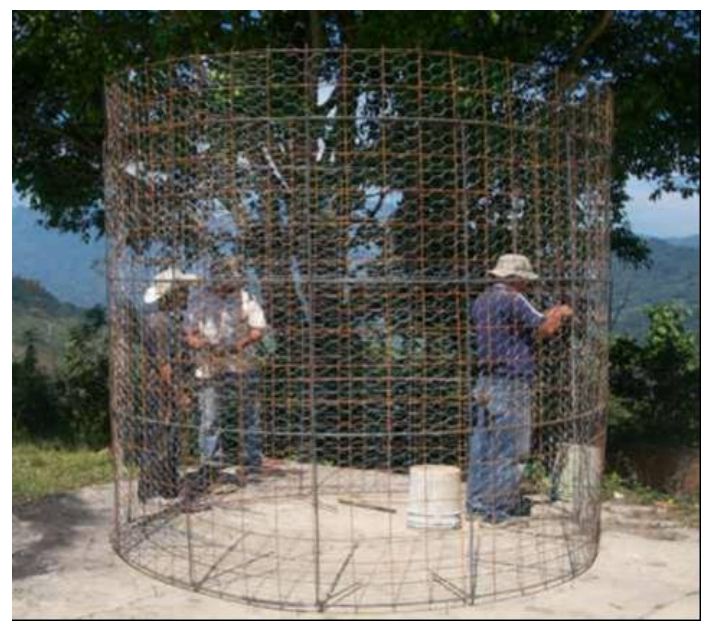

Photo 4. Ferrocement CALLD [24].

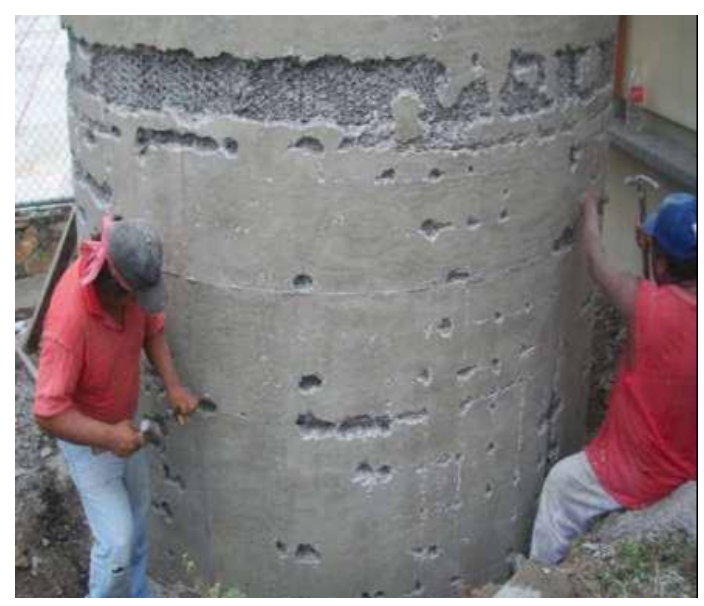

Photo 5. Constructive process, exterior finish [24].

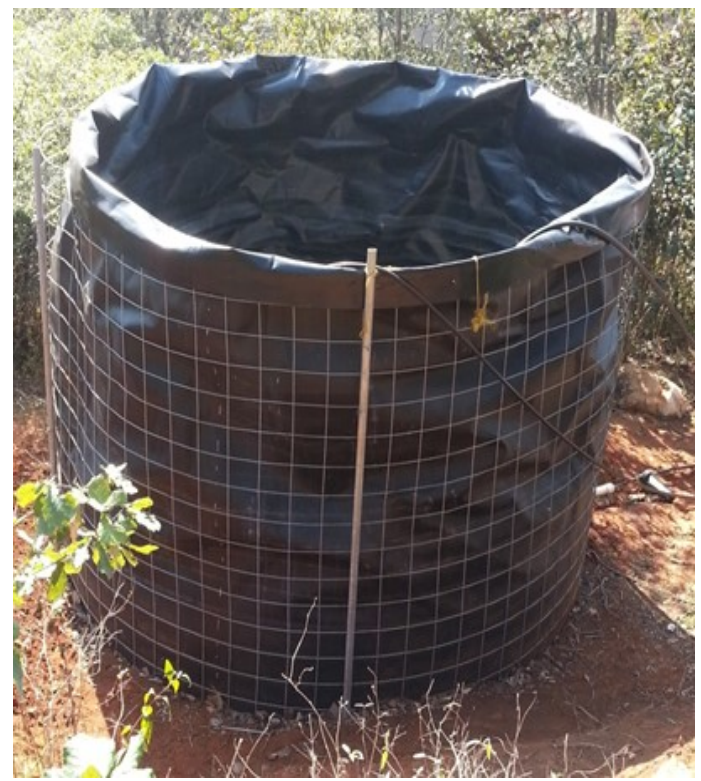

Photo 6. Flexible CALLD. 
The RHS flexible has two ways for water supply: using a flexible hose that works as a siphon or through a pipe with a control valve.

When these deposits are designed to store 10,000 liters or more, we must take into consideration that the structure is not too slender to avoid oscillation provoked by ground acceleration in earthquakes. For this reason, the height vs diameter relationship must be close to the unit, so the RHS flexible has to comply with the following slenderness ratio:

$$
1<\frac{h}{D}<1.5
$$

Thus, the RHS flexible is an economic alternative that provides a solution to water supply problems through rainwater harvest.

\section{Cost Comparison}

Regardless of which rainwater harvest system is used, these options are the most economic to supply quality water to small rural communities in Mexico, especially in areas without close water sources (rivers, lakes, streams, groundwater), which is the case of hundreds of indigenous people in the country.

To compare the prices of the four systems, we considered the unit prices for a $15 \mathrm{~m}^{3}$ RHS. The calculations cover special building circumstances, so the concepts include material, tools, and workforce costs. The sum of these three values represents the direct cost, and to the result, we added the percentages of indirect costs and utility. Table 3 shows the price comparison of the four rainwater harvest systems.

\section{Conclusions}

For hundreds of indigenous communities in Mexico living in the highlands of the country or places with no superficial or subterranean water sources, rainwater harvest through "Community RHSs" or "Home RHSs" is the only option for water supply. We must study the cost of designing and building these systems in thousands of impoverished communities in Latin America and Mexico, where it will become a solution for water supply.

This work introduces four rainwater harvest systems, two rigid: The "RHS ferrocement" and "RHS cappuccino", and two flexible: the "RHS industrial" (rotoplas) and "RHS flexible". The cost of the commercial and flexible systems with a 15,000-liter storage volume is similar, typically costing 0.17 USD per

Table 3. Cost comparison of four home rainwater harvest systems of $15 \mathrm{~m}^{3}$.

\begin{tabular}{ccc}
\hline RSH & TOTAL COST (USD) & COST FOR EACH LITER STORAGE (USD) \\
\hline CAPUCCINNO & 2627 & 0.1751 \\
FERROCEMENT & 2695 & 0.1796 \\
INDUSTRIAL & 2518 & 0.1678 \\
FLEXIBLE & 899 & 0.0599 \\
\hline
\end{tabular}


stored liter. However, the disadvantage of a commercial system is their low durability and that they are not manufactured for higher volume storage (at least not in Mexico). The rigid system is more resistant, but is more expensive than RHS flexible. Thus three flexible systems can be built for the price of one rigid system and it costs 0.06 USD per stored liter. Thus, this research work contributes not only to present four types of rain water collection home (at least two of them unpublished), but also to the hydraulic design of RHS considering climate change effects, both natural and anthropogenic.

\section{Acknowledgements}

Special thanks to Laura Montserrat Mundo-Navarro for reviewing this paper.

\section{Conflicts of Interest}

The authors declare no conflicts of interest regarding the publication of this paper.

\section{References}

[1] CONAGUA (2006) Síntesis del IV foro mundial del agua. Comisión Nacional del Agua (CONAGUA), México, D.F.

[2] Fernández, C.G. (2009) La crisis del agua en América Latina. Revista de estudios culturales, 2, 80-96.

[3] Jouravlev, A. (2001) Administración del agua en América Latina y el Caribe en el umbral del siglo XXI. División de Recursos Naturales e Infraestructura, CEPAL, Organización de las Naciones Unidas, Santiago de Chile.

http://aquabook.agua.gob.ar/files/upload/contenidos/10_1/AmLatina-Caribe-Admi nisdelagua_es.pdf

[4] Mundo-Molina, M. (2015) Climate Change Effects on Evapotranspiration in Mexico. American Journal of Climate Change, 4, 163-172.

https://doi.org/10.4236/ajcc.2015.42012

[5] Delgado, R.G. (2007) Integración competitiva: Latrocinio, función de los corredores multinacionales del TLCAN: agua, energía y competitividad. Global Research. http://www.globalresearch.ca/

[6] LAN (1992) Ley de aguas nacionales. Nueva ley publicada en el Diario Oficial de la Federación (DOF) el 1 de diciembre de 1992, reformada y publicada en el DOF el 24 de marzo de 2016. México, D.F.

[7] CONAGUA (2009) Régimen de almacenamiento y extracciones de la presa Danxho. Jefatura del Distrito de Riego de Jilotepec, Estado de México, México.

[8] Segrelles, S.J.A. (2007) Geopolítica del agua en América Latina: dependencia, exclusión y privatización. XVI Simposio polaco-mexicano, Universidad de Varsovia, Polonia.

[9] CONAGUA (2016) Estadísticas del agua en México. Comisión Nacional del Agua. México, D.F.

[10] Breña, P.A. and Breña, N.A. (2007) Disponibilidad de agua en el futuro de México. Revista Ciencia, 58, 64-71.

[11] Malvezzi, R. (2006) La cuestión del agua en América Latina. http://www.bolpress.com/art.php?Cod=2006020103 
[12] Sainz, J. and Becerra, M. (2003) Los conflictos por agua en México. Gaceta Ecológica, 67, 61-68.

[13] OECD (2015) Territorial Reviews: Valle de México, Mexico. Organization for Economic Cooperation and Development, OECD Publishing, Paris.

[14] CONAGUA (2016) Numeragua México 2016. Comisión Nacional del Agua. México, D.F.

[15] Mundo-Molina, M. (2016) Supplying System for Drinking Water to Small Rural Communities with Zero Greenhouse Gasses: Sixteen Years of Experiences in Mexico. Journal of Water Resource and Protection, 8, 1044-1052. https://doi.org/10.4236/jwarp.2016.812083

[16] INEGI (2000) Censo general de población y vivienda 2000. Instituto Nacional de Estadística y Geografía e Informática (INEGI).

http://www.inegi.org.mx/inegi/contenidos/espanol/eventos/vigenero/dia29/panel4_ mesas/Poblacion_indigena/P_indigena-en-Mexico.pdf

[17] INI (1993) Indicadores socioeconómicos de los pueblos indígenas de México, 1990. Subdirección de Investigación, Instituto Nacional Indigenista.

[18] INI (1999) Información básica sobre los pueblos indígenas de México. Instituto Nacional Indigenista.

[19] CONAGUA (2009) Situación del subsector agua potable, alcantarillado y saneamiento 2009. Subdirección General de Agua Potable, Drenaje y Saneamiento. Coordinación General de Atención Institucional. Comunicación y Cultura del Agua de la Comisión Nacional del Agua, México.

[20] ANUIES (2014) Iniciativa de Reforma de la Ley de Aguas Nacionales. Universidad Autónoma de Baja California.

https://www.youtube.com/watch?v=34-j2QjXu7o\&t=84s

[21] CONAGUA (2008) Estadísticas del agua en México. Comisión Nacional del Agua (CONAGUA), México.

[22] Anaya, G.M. (1998) Sistema de captación de agua de lluvia para uso domético en América Latina y El Caribe. Agencia de cooperación técnica IICA-México, México.

[23] Hernádez, M. (2008) Captación de agua de lluvia como alternativa para afrontar la escasez del recurso. Global Environment Management. Technical Report, University of Windsor.

[24] INESA (2016) Transferencia de tecnologías alternativas para la captación de aguas pluviales. Instituto Estatal del Agua (INESA) Gobierno Estatal de Chiapas.

[25] OMM (2011) Guía de prácticas climatológicas. OMM No. 100. Organización Meteorológica Mundial (OMM) Ginebra, Suiza.

[26] Mundo, M.M. (2017) Análisis de los procesos cíclicos de enfriamiento-calentamiento y anomalías de las temperaturas máximas y mínimas de la estación meteorológica 07205 ubicada en la meseta comiteca de la RH Grijalva Usumacinta, en el marco de la inestabilidad climática global. In: La cuenca del Río Usumacinta desde la perspectiva del cambio. Instituto Mexicano de Tecnología del Agua. Jiutepec, Morelos, México. 